\title{
Hubungan Sarana Pembelajaran dan Motivasi Belajar dengan Hasil Belajar IPS
}

\author{
Ni Made Cintya Bawanti Dewi ${ }^{1 *}$, I Made Tegeh ${ }^{2}$, I Wayan Suwatra ${ }^{3}$
}

${ }^{1}$ Jurusan Pendidikan Guru Sekolah Dasar, Universitas Pendidikan Ganesha, Indonesia

2,3Jurusan Teknoligi Pendidikan, Universitas Pendidikan Ganesha, Indonesia

\author{
ARTICLEINFO \\ Article history: \\ Received 18 May 2019 \\ Received in revised form \\ 30 June 2019 \\ Accepted 15 July 2019 \\ Available online 25 August \\ 2019 \\ Kata Kunci: \\ Sarana pembelajaran, \\ motivasi siswa, hasil \\ belajar IPS \\ Keywords: \\ Learning facilities, \\ student motivation, IPS \\ learning results
}

\begin{abstract}
A B S T R A K
Penelitian ini bertujuan untuk mengetahui ada atau tidaknya hubungan antara sarana pembelajaran dan motivasi belajar dengan hasil belajar IPS siswa kelas IV SD Gugus V di Kecamatan Karangasem. Penelitian ini termasuk jenis penelitian korelasional. Populasi penelitian ini adalah seluruh siswa kelas IV SD Gugus V di Kecamatan Karangasem. Sampel yang diambil dalam penelitian ini adalah teknik random sampling dengan jumlah sampel sebanyak 127 siswa. Data yang telah dikumpulkan dianalisis dengan menggunakan analisis statistik deskriptif dan analisis regresi. Hasil dari uji hipotesis adalah: (1) terdapat hubungan yang positif dan signifikan antara sarana pembelajaran dengan hasil belajar IPS dengan $r_{\text {hitung }}$ sebesar 0,311 dan koefisien determinasinya sebesar 9,7\%. (2) terdapat hubungan yang positif dan signifikan antara motivasi belajar dengan hasil belajar IPS dengan $r_{\text {hitung }}$ sebesar 0,402 dan koefisien determinasinya sebesar $=$ $16,2 \%$. (3) terdapat hubungan yang positif dan signifikan antara sarana pembelajaran dan motivasi belajar dengan hasil belajar IPS dengan $r_{\text {hitung }}$ sebesar 0,408 dan koefisien determinasinya sebesar $=16,6 \%$. Dengan demikian dapat disimpulkan terdapat hubungan yang positif dan signifikan antara sarana pembelajaran dan motivasi belajar dengan hasil belajar IPS baik secara sendiri-sendiri maupun secara bersama.
\end{abstract}

\section{A B S T R A C T}

This research aimed to determine whether or not the correlation between the learning faciities and student motivation with the results of IPS students learning at fourth elementary school in cluster $\mathrm{V}$ Karangasem district. This research was correlational research. The populations of this research were all IV graders of elementary school in cluster V Karangasem district. Samples taken by random sampling technique with total sample were 127 students. The data that have been collected analyzed by descriptive statistic technique and regression analysis. The results of the hypothesis test is: (1) there is a positive and significant the correlation between the learning facilities with IPS learning results of 0.311 and the coefficient of determination is $9.7 \%$.(2) there is a positive and significant the correlation between the student's motivation with IPS learning result of 0,402 and coefficient of determination is $=16,2 \%$. (3) there is a positive and significant the correlation between learning facilities and student motivation with IPS learning result of $=0,408$ and coefficient of determination equal to $=16,6 \%$. Thus it can be concluded there is a positive and significant the correlation between the learning facilities and student motivation with the results of IPS student learning both individually and collectively.

\footnotetext{
${ }^{1}$ Corresponding author.

E-mail addresses: Cintya.bawantidewi@yahoo.com (Ni Made Cintya Bawanti Dewi)
} 


\section{Pendahuluan}

Pendidikan adalah hal terpenting bagi setiap negara untuk dapat berkembang pesat. Negara yang hebat akan menempatkan pendidikan sebagai prioritas pertamanya, karena dengan pendidikan, kemiskinan pada rakyat di negara tersebut akan dapat tergantikan menjadi kesejahteraan. Bagaimanapun, dalam perkembangannya, pendidikan di Indonesia senantiasa harus menghadapi beberapa masalah di setiap tahapnya. Masalahmasalah tersebut hanya dapat diselesaikan dengan partisipasi dari semua pihak yang terkait di dalam sistem pendidikan, seperti orangtua, guru-guru, kepala sekolah, masyarakat, dan juga peserta didik itu sendiri. Pada fase input, orangtua memiliki kontribusi besar dalam memperkenalkan nilai-nilai baik kepada anak-anak mereka. Orangtua bertanggung jawab penuh untuk mendidik anak-anak mereka dengan nilai-nilai kepemimpinan, sehingga mereka mempunyai bekal yang cukup untuk menjadi cikal bakal pemimpin ketika mereka mulai memasuki institusi formal, seperti sekolah. Pada fase proses, orangtua bekerjasama dengan para guru dan kepala sekolah untuk memberikan penguatan kepada peserta didik dalam menerapkan nilai-nilai kepempinan yang baik melalui budaya organisasi di sekolah. Terakhir, pada tahap output, peserta didik harus menghadapi begitu banyak tantangan di dunia nyata, di luar sekolah. Peserta didik yang sudah melalui tahap-tahap sebelumnya di sekolah dengan budaya organisasi yang mengajarkan dan membiasakan nilainilai baik dalam hidupnya, maka akan tumbuh menjadi pemimpin yang hebat untuk negara ini (Megawati, 2012).

Pendidikan merupakan sebuah sistem. Sebagai sistem, aktivitas pendidikan terbangun dalam beberapa komponen, yaitu pendidik, peserta didik, tujuan pendidikan, alat pendidikan, dan lingkungan pendidikan. Semua komponen yang membangun sistem pendidikan, saling berhubungan, saling tergantung, dan saling menentukan satu sama lain. Setiap komponen memiliki fungsi masing-masing dalam rangka mencapai tujuan pendidikan. Aktivitas pendidikan akan terselenggara dengan baik apabila didukung oleh komponen-komponen dimaksud. Fungsi pendidikan sebenarnya adalah menyediakan fasilitas yang dapat memungkinkan tugas pendidikan dapat berjalan lancar, baik secara struktural, maupun secara institusional. Secara struktural menuntut terwujudnya struktur organisasi yang mengatur jalannya proses kependidikan. Secara institusional mengandung implikasi bahwa proses kependidikan yang terjadi dalam struktur organisasi itu dilembagakan untuk lebih menjamin proses pendidikan itu berjalan secara konsisten dan berkesinambungan mengikuti kebutuhan dan perkembangan manusia yang cenderung ke arah tingkat kemampuan yang optimal (Saat, 2015).

Pasal 1 UU SISDIKNAS no. 20 tahun 2003 disebutkan bahwa Sistem Pendidikan Nasional adalah keseluruhan komponen pendidikan yang saling terkait secara terpadu untuk mencapai tujuan pendidikan nasional. Berangkat dari bunyi pasal ini dapat diketahui bahwa pendidikan adalah sistem yang merupakan suatu totalitas struktur yang terdiri dari komponen yang saling terkait dan secara bersama menuju kepada tercapainya tujuan (Soetarno, 2003: 2). Adapun komponen-komponen dalam pendidikan nasional antara lain adalah lingkungan, sarana-prasarana, sumberdaya, dan masyarakat. Komponenkomponen tersebut bekerja secara bersama-sama, saling terkait dan mendukung dalam mencapai tujuan pendidikan. Tujuan pendidikan nasional yang dirumuskan dalam UU SISDIKNAS adalah untuk mengembangkan potensi anak didik agar menjadi manusia yang beriman dan bertakwa kepada Tuhan Yang Maha Esa, berakhlak mulia, sehat, berilmu, cakap, kreatif, mandiri, dan menjadi warga Negara yang demokratis serta bertanggung jawab (Munirah,2015).

Sekolah merupakan lembaga pendidikan formal pertama yang sangat penting dalam menentukan keberhasilan belajar peserta didik. Sebuah sekolah pasti memerlukan sarana dan prasarana untuk melangsungkan proses belajar mengajar. Adanya sarana dan prasarana pembelajaran banyak membantu kelangsungan belajar mengajar di sekolah. Hal ini merupakan faktor yang harus diperhatikan karena mempengaruhi kelangsungan proses belajar mengajar di sekolah

Dalam proses pembelajaran selain sarana pembelajaran, motivasi juga memegang peranan yang penting dalam mencapai hasil belajar siswa. Motivasi yang dimiliki siswa akan menentukan hasil yang dicapai dari aktivitas pembelajaran. Motivasi untuk belajar merupakan kondisi psikis yang dapat mendorong seseorang untuk belajar. Besarnya motivasi setiap siswa dalam belajar berbeda-beda.Tinggirendahnya motivasi siswa tergantung pada faktor-faktor dari siswa itu sendiri, baik dari faktor instriksik maupun ekstrinsik. Faktor intrinsik berasal dari dalam diri siswa tersebut, sedangkan faktor ekstrinsik berasal dari luar diri siswa seperti faktor lingkungan, keluarga, teman, dan sebagainya.

Sarana pembelajaran dan motivasi dibutuhkan di setiap mata pelajaran, salah satunya yaitu mata pelajaran IPS. Ilmu Pengetahuan Sosial (IPS) merupakan suatu disiplin ilmu yang dipelajari di sekolah dasar. Segala bentuk pengalaman atau pengetahuan tersebut menjadi bagian dari sejarah yang terus diingat bahkan menjadi guru sehingga tidak akan mengulangi kesalahan yang sama. Pendidikan IPS penting diberikan kepada siswa pada jenjang pendidikan dasar karena siswa sebagai anggota masyarakat 
perlu mengenal masyarakat dan lingkungannya. Untuk mengenal masyarakat siswa dapat belajar melalui media cetak, media elektronika, maupun secara langsung melalui pengalaman hidupnya di tengah-tengah masyarakat. Dengan pelajaran IPS, diharapkan siswa dapat memiliki sifat peka dan tanggap untuk bertindak secara rasional dan bertanggung jawab dalam memecahkan masalah sosial yang dihadapi dalam kehidupannya.

"Motivasi adalah dorongan dasar yang menggerakkan orang bertingkah laku" (Uno, 2008:1). Sardiman (dalam Kardi, 2013:5) menyatakan bahwa "motivasi siswa dapat juga diartikan sebagai serangkaian usaha untuk menyediakan kondisi-kondisi tertentu, sehingga seseorang mau dan ingin melakukan sesuatu, dan bila ia tidak suka, maka akan berusaha untuk meniadakan atau mengelak perasaan tidak suka itu". Motivasi juga dapat diartikan sesuatu yang dibutuhkan untuk melakukan aktivitas. Salah satu aktivitas yang dimaksud yaitu belajar. Apabila anak sudah memiliki motivasi, belajar akan menjadi menyenangkan.

Menurut Suprijono (2012:5), hasil belajar adalah polapola perbuatan, nilai-nilai, pengertianpengertian, sikapsikap, apresiasi dan keterampilan. Selanjutnya Supratiknya (2012:5) mengemukakan bahwa hasil belajar yang menjadi objek penilaian kelas berupa kemampuan-kemampuan baru yang diperoleh siswa setelah mereka mengikuti proses belajar-mengajar tentang mata pelajaran tertentu. Dalam sistem pendidikan nasional rumusan tujuan pendidikan mengacu pada klasifikasi hasil belajar dari Bloom yang secara garis besar yaitu aspek kognitif, aspek afektif dan aspek psikomotor (Widodo, 2013).

Selain dua variabel yang telah dijelaskan tadi, masih banyak variabel-variabel lain yang mempengaruhi hasil belajar seperti: disiplin siswa, motivasi berprestasi, ekonomi orang tua, pola asuh orang tua, dan lain-lain. Namun, dalam penelitian ini yang dibahas hanya variabel sarana pembelajaran dan motivasi siswa. Masing-masing variabel yaitu sarana pembelajaran dan motivasi siswa berkontribusi terhadap hasil belajar IPS. Jika sarana pembelajaran lengkap maka berkontribusi dapat menunjang aktivitas belajar siswa sehingga hasil belajar siswa dapat meningkat. Apabila motivasi siswa tinggi, maka aktivitas belajar siswa juga tinggi sehingga dapat meningkatkan hasil belajar siswa. Dengan demikian, diduga kedua variabel tersebut memiliki kontribusi yang memadai terhadap hasil belajar IPS. Sekolah yang memiliki sarana pembelajaran yang lengkap dan motivasi siswa yang tinggi, maka siswa dapat mencapai hasil belajar IPS yang optimal. Begitu pula sebaliknya, apabila sarana pembelajaran kurang memadai dan motivasi siswa kurang diduga hasil belajar siswa akan rendah.

Berdasarkan hasil wawancara dengan guru kelas IV dikatakan bahwa penyediaan sarana pembelajaran yang lengkap dan memadai oleh pihak sekolah menjadi penunjang hasil belajar siswa, namun pada kenyataannya sarana pembelajaran yang disediakan oleh pihak sekolah belum memadai kebutuhan siswa seperti buku penunjang pembelajaran selain buku paket siswa, media pembelajaran IPS di kelas terbatas seperti media gambar, gambar pahlawan, buku paket maupun globe. Selain sarana pembelajaran, motivasi siswa juga sangat penting hubungannya dengan hasil belajar siswa. Motivasi siswa masih rendah terlihat dari kurangnya ketekunan, keuletan serta menunjukkan minat yang rendah terhadap materi IPS dan tugas yang diberikan.Hal tersebut menyebabkan hasil belajar siswa kurang optimal. Setelah dihitung 63\% siswa belum mampu mencapai nilai KKM yang sudah ditentukan. Jadi, nilai UAS siswa kelas IV SD di Gugus V Kecamatan Karangasem masih tergolong rendah. Sedangkan jika mengacu pada pedoman pembelajaran siswa dikatakan tuntas belajar jika ketuntasan klasikal minimal 85\%, maksudnya $85 \%$ atau lebih siswa sudah tuntas secara individu. Berdasarkan hal tersebut, hasil belajar IPS siswa tentu dipengaruhi oleh berbagai faktor, baik faktor internal maupun faktor eksternal.

\section{Metode}

Penelitian ini dilaksanakan di SD Gugus V Kecamatan Karangasem pada rentang waktu semester II (Genap) pada tahun pelajaran 2017/2018. Penelitian ini merupakan penelitian ex post facto, karena upaya pendekatan terhadap gejala penelitian dilakukan secara wajar apa adanya tanpa melakukan manipulasi terhadap gejala yang diteliti. "Ex post facto adalah suatu penelitian empiris dan sistematis, dimana peneliti tidak melakukan pengendalian (kontrol) terhadap variabel bebas secara langsung, karena perwujudan variabel tersebut pada dasarnya memang tidak dapat dimanipulasi" (Agung, 2014:210).

Penelitian ini dilaksanakan dengan menggunakan pendekatan asosiatif kuantitatif.Pendekatan asosiatif kuantitatif merupakan penelitian berupa angka-angka dan analisis menggunakan statistik.Penelitian ini bertujuan untuk menjelaskan hubungan variabel bebas yaitu sarana prasarana $\left(\mathrm{X}_{1}\right)$ dan motivasi belajar $\left(\mathrm{X}_{2}\right)$ dengan hasil belajar IPS (Y).

Penelitian ini dilaksanakan di SD Gugus V Kecamatan Karangasem pada rentang waktu semester II (Genap) pada tahun pelajaran 2017/2018. 
Populasi dalam penelitian ini adalah seluruh siswa kelas IV SD di Gugus V Kecamatan Karangasem Kabupaten Karangasem yaitu sebanyak 200 siswa. Jumlah siswa yang dijadikan sampel secara keseluruhan di gugus V Kecamatan Karangasem sebanyak 127 orang.

Untuk mengetahui tentang sarana pembelajaran dan motivasi siswa, peneliti menggunakan angket/kuisioner. Adapun cara untuk memberikan skor adalah 5 untuk sangat sesuai, 4 untuk sesuai, 3 untuk cukup sesuai, 2 untuk kurang sesuai dan 1 untuk tidak sesuai. Pernyataan pada angket atau kuisioner berjumlah 30 item. Untuk data tentang hasil belajar IPS, diperoleh dari hasil ulangan akhir semester ganjil tahun ajaran 2017/2018 dengan metode pencatatan dokumen.

Dalam penelitian ini menggunakan teknis analisis data dengan menggunakan dua jenis yaitu menggunakan analisis statisktik deskriptif dan analisis regresi. Untuk memenuhi persyaratan uji statistik diatas, maka perlu dilakukan uji prasyarat analisis yang meliputi: (1) uji normalitas, (2) uji linieritas, dan (3) uji multikolinieritas.

\section{Hasil dan Pembahasan}

Data yang diperoleh dalam penelitian ini adalah data tentang sarana pembelajaran, data tentang motivasi siswa dan data tentang hasil belajar IPS.Data yang didapatkan tersebut kemudian dikelompokkan nilainya menjadi tiga kelompok, yaitu kelompok data sarana pembelajaran $\left(\mathrm{X}_{1}\right)$, kelompok data motivasi siswa $\left(\mathrm{X}_{2}\right)$ dan data kelompok hasil belajar IPS (Y).

Data yang diperoleh dan penelitian tentang sarana pembelajaran, motivasi siswa dan hasil belajar IPS siswa pada siswa kelas IV SD di Gugus V Kecamatan Karangasem Tahun Pelajaran 2017/2018 diurutkan dari skor terbesar ke skor terkecil. Selanjutnya disusun secara sistematik dan disajikan dalam bentuk tabel distribusi frekuensi dan dalam bentuk diagram batang.

Tabel 1. Rekapitulasi Hasil Uji Normalitas Variabel

\begin{tabular}{lcc}
\hline \multicolumn{1}{c}{ Variabel } & $\mathbf{r}_{\text {tabel }}$ & $\mathbf{r}_{\text {hitung }}$ \\
Sarana Pembelajaran & & 0,113 \\
Motivasi Siswa & 0,05 & 0,065 \\
Hasil Belajar IPS & & 0,097 \\
\hline
\end{tabular}

Tabel 1 menunjukkan bahwa uji normalitas sarana pembelajaran $\left(\mathrm{X}_{1}\right)$, motivasi siswa $\left(\mathrm{X}_{2}\right)$ dan hasil belajar IPS (Y) memperoleh nilai lebih besar dari 0,05 maka dapat disimpulkan bahwa sarana pembelajaran $\left(\mathrm{X}_{1}\right)$, motivasi siswa $\left(\mathrm{X}_{2}\right)$ dan hasil belajar IPS $(\mathrm{Y})$ berdistribusi normal.

Tabel 2 . Rekapitulasi Hasil Uji Linieritas Variabel

\begin{tabular}{lcc}
\hline \multicolumn{1}{c}{ Variabel } & $\mathbf{r}_{\text {tabel }}$ & $\mathbf{r}_{\text {hitung }}$ \\
Sarana Pembelajaran (X1) dengan Hasil Belajar IPS (Y) & \multirow{2}{*}{0,05} & 0,967 \\
Motivasi Siswa (X2) dengan Hasil Belajar IPS (Y) & & 1,072 \\
\hline
\end{tabular}

Tabel 2 menunjukkan bahwa uji linieritas antara sarana pembelajaran ( $\left.\mathrm{X}_{1}\right)$ dengan hasil belajar IPS $(\mathrm{Y})$, dan motivasi siswa $\left(\mathrm{X}_{2}\right)$ dengan hasil belajar IPS $(\mathrm{Y})$ memperoleh $\mathrm{r}_{\text {hitung }}$ lebih besar dari 0,05 maka dapat disimpulkan bahwa data bersifat linier atau berarti.

Tabel 3. Hasil Uji Multikolinieritas

\begin{tabular}{|c|c|c|c|c|c|c|c|}
\hline \multirow[b]{2}{*}{ Model } & \multicolumn{2}{|c|}{$\begin{array}{c}\text { Unstandardized } \\
\text { Coefficients }\end{array}$} & \multirow{2}{*}{$\begin{array}{c}\begin{array}{c}\text { Standardiz } \\
\text { ed } \\
\text { Coefficients }\end{array} \\
\text { Beta }\end{array}$} & \multirow[b]{2}{*}{$\mathrm{t}$} & \multirow[b]{2}{*}{ Sig. } & \multicolumn{2}{|c|}{ Collinearity Statistics } \\
\hline & $\mathrm{B}$ & Std. Error & & & & Tolerance & VIF \\
\hline 1 (Constant) & 58.315 & 5.402 & & 10.796 & .000 & & \\
\hline Sarana Pembelajaran & .053 & .064 & .089 & .825 & .411 & .582 & 1.718 \\
\hline Motivasi Siswa & .132 & .041 & .345 & 3.205 & .002 & .582 & 1.718 \\
\hline
\end{tabular}

Dilihat dari Tabel 3 nilai tolerance variabel sarana pembelajaran ( $\mathrm{x} 1$ ) dan motivasi siswa (x2) yakni 0,582 lebih besar dari 0,10. Sementara itu, nilai VIF variabel sarana pembelajaran (x1) dan motivasi siswa (x2) yakni 1,718 lebih kecil dari 10,00. Sehingga dapat disimpulkan tidak terjadi Multikolinieritas. 
Setelah dilakukan uji prasyarat analisis, semua syarat untuk melakukan uji hipotesis terpenuhi, selanjutnya dibuat pengujian hipotesis.

Hipotesis I berbunyi bahwa "Terdapat Hubungan Signifikan Antara Sarana pembelajaran dengan Hasil Belajar IPS Siswa Kelas IV SD di Gugus V Kecamatan Karangasem tahun pelajaran 2017/2018" Berdasarkan analisis yang dilakukan dengan menggunakan bantuan program IBM SPSS Statistic diperoleh hasil sebagai berikut.

Tabel 4. Hasil Analisis Besar Koefisien Korelasi $\mathrm{X}_{1}{ }^{*} \mathrm{Y}$

\begin{tabular}{lrrrr}
\hline Model & R & R Square & Adjusted R Square & \multicolumn{2}{c}{ Std. Error of the Estimate } \\
\hline 1 & $.311^{\mathrm{a}}$ & .097 & .090 & 4.268 \\
\hline
\end{tabular}

Hasil output IBM SPSS Statistic Dari hasil Outpus SPSS pada Tabel 04 diperoleh besar kontribusi sarana pembelajaran terhadap hasil belajar IPS siswa kelas IV di SD di Gugus V Kecamatan Karangasem , (r) yaitu 0,311 apabila dibandingkan dengan harga $r_{\text {tabel }}$ pada taraf signifikansi 5\% yakni 0,176 jadi dapat disimpulkan bahwa $\mathrm{r}_{\text {hitung }} 0,311>\mathrm{r}_{\text {tabel }}$ 0,176 maka $\mathrm{H}_{0}$ ditolak yang berarti signifikan. Sedangkan besar koefisien determinasinya $\left(\mathrm{r}^{2}\right)=0,097$ jadi $0,097 \times 100 \%=9,7 \%$. Jadi besar koefisien determinasinya adalah $9,7 \%$.

Tabel 5. Hasil Analisis Besar Koefisien Korelasi $\mathrm{X}_{1}{ }^{*} \mathrm{Y}$

\begin{tabular}{|c|c|c|c|c|c|c|c|c|}
\hline Model & & Sum of Squares & $\mathrm{df}$ & & $\begin{array}{c}\text { Mean } \\
\text { Square }\end{array}$ & $\mathrm{F}$ & Sig. & \\
\hline \multirow[t]{3}{*}{1} & Regression & 244.662 & & 1 & 244.662 & $\begin{array}{r}13.43 \\
1\end{array}$ & & $.000^{\mathrm{b}}$ \\
\hline & Residual & 2277.070 & & 125 & 18.217 & & & \\
\hline & Total & 2521.732 & & 126 & & & & \\
\hline
\end{tabular}

Tabel 05 menunjukkan bahwa harga $F_{\text {hitung }}$ sebesar 13,431 dengan tingkat signifikansi 0,000< 0,05, maka model regresi dapat dipakai untuk memprediksi variabel hasil belajar IPS

Tabel 6. Hasil Analisis Regresi Sederhana $\mathrm{X}_{1}{ }^{*} \mathrm{Y}$

\begin{tabular}{|c|c|c|c|c|c|c|}
\hline \multirow[b]{2}{*}{ Model } & \multicolumn{2}{|c|}{$\begin{array}{l}\text { Unstandardized } \\
\text { Coefficients }\end{array}$} & \multirow{2}{*}{$\begin{array}{c}\text { Standardized } \\
\text { Coefficients }\end{array}$} & \multirow[b]{2}{*}{$\mathrm{T}$} & \multirow[b]{2}{*}{ Sig. } & \\
\hline & $\mathrm{B}$ & Std. Error & & & & \\
\hline 1 (Constant) & 59.036 & 5.594 & & 10.554 & & .000 \\
\hline Sarana Pembelajaran & .186 & .051 & .311 & 3.665 & & .000 \\
\hline
\end{tabular}

Dari hasil perhitungan SPSS pada Tabel 06 diperoleh persamaan regresinya dapat ditulus $\mathrm{Y}=$ $59,036+0,186$. Diketahui pada tabel t hitung $=3,665$ dengan nilai signifikansi $0,000<0,05$, maka Ho ditolak dan H1 diterima. Dengan demikian hipotesis yang menyatakan terdapat hubungan signifikan antara sarana pembelajaran dengan hasil belajar IPS siswa kelas IV SD di Gugus V Kecamatan Karangasem tahun pelajaran 2017/2018, diterima.

Hipotesis II Berbunyi bawha "terdapat hubungan signifikan antara motivasi siswa dengan hasil belajar IPS siswa kelas IV di SD Gugus V Kecamatan Karangasem Tahun Pelajaran 2017/2018". Berdasarkan analisis yang dilakukan dengan berbantuan program IBM SPSS Statistic diperoleh hasil sebagai berikut.

Tabel 7. Hasil Analisis Besar Koefisien Korelasi $\mathrm{X}_{2}{ }^{*} \mathrm{Y}$

\begin{tabular}{lrrrr}
\hline Model & R & R Square & Adjusted R Square & \multicolumn{1}{c}{ Std. Error of the Estimate } \\
\hline 1 & $.402^{\mathrm{a}}$ & .162 & .155 & 4.113 \\
\hline
\end{tabular}

Hasil output IBM SPSS Statistic Dari hasil Outpus SPSS pada Tabel 07 diperoleh besar kontribusi motivasi siswa terhadap hasil belajar IPS siswa kelas IV di SD di Gugus V Kecamatan Karangasem , (r) 
yaitu 0,402 apabila dibandingkan dengan harga $r_{\text {tabel }}$ pada taraf signifikansi $5 \%$ yakni 0,176 jadi dapat disimpulkan bahwa $r_{\text {hitung }} 0,402>r_{\text {tabel }}$ 0,176 maka $\mathrm{H}_{0}$ ditolak yang berarti signifikan. Sedangkan besar koefisien determinasinya $\left(\mathrm{r}^{2}\right)=0,162$ jadi $0,162 \times 100 \%=16,6 \%$. Jadi besar koefisien determinasinya adalah $16,2 \%$.

Tabel 8. Hasil Analisis Besar Koefisien Korelasi $\mathrm{X}_{2}{ }^{*} \mathrm{Y}$

\begin{tabular}{llrrrrr}
\hline Model & & Sum of Squares & df & Mean Square & F & Sig. \\
\hline 1 & Regression & 407.284 & 1 & 407.284 & 24.077 & $.000^{\mathrm{b}}$ \\
& Residual & 2114.448 & 125 & 16.916 & & \\
& Total & 2521.732 & 126 & & & \\
\hline
\end{tabular}

Tabel 8 menunjukkan bahwa harga $F_{\text {hitung }}$ sebesar 24,077 dengan tingkat signifikansi 0,000 0,05, maka model regresi dapat dipakai untuk memprediksi variabel hasil belajar IPS.

Tabel 9. Hasil Analisis Regresi Sederhana $\mathrm{X}_{2}{ }^{*} \mathrm{Y}$

\begin{tabular}{|c|c|c|c|c|c|c|}
\hline \multirow{2}{*}{\multicolumn{2}{|c|}{ Model }} & \multicolumn{5}{|c|}{$\begin{array}{l}\text { Standardized } \\
\text { Coefficients }\end{array}$} \\
\hline & & $\mathrm{B}$ & Std. Error & Beta & $\mathrm{t}$ & Sig. \\
\hline \multirow[t]{2}{*}{1} & (Constant) & 61.585 & 3.667 & & 16.796 & .000 \\
\hline & $\begin{array}{l}\text { Motivasi } \\
\text { Siswa }\end{array}$ & .153 & .031 & .402 & 4.907 & .000 \\
\hline
\end{tabular}

Dari hasil perhitungan SPSS pada Tabel 9 diperoleh persamaan regresinya dapat ditulus $\mathrm{Y}=61,585$ $+0,153 X$. Diketahui pada tabel $t$ hitung $=4,907$ dengan nilai signifikansi $0,000<0,05$, maka Ho ditolak dan H1 diterima. Dengan demikian hipotesis yang menyatakan terdapat hubungan signifikan antara motivasi siswa dengan hasil belajar IPS siswa kelas IV SD di Gugus V Kecamatan Karangasem tahun pelajaran 2017/2018, diterima.

Hipotesis III berbunyi bahwa " terdapat hubungan signifikan antara sarana pembelajaran dan motivasi siswa dengan hasil belajar IPS siswa kelas IV semester II di SD Gugus V Kecamatan Karangasem tahun pelajaran 2017/2018". Berdasarkan analisis dengan berbantuan program IBM SPSS Statistic diperoleh hasil sebagai berikut.

Tabel 10. Hasil Analisis Besar Koefisien Regresi Ganda $\mathrm{X}_{1} \mathrm{X}_{2}{ }^{*} \mathrm{Y}$

\begin{tabular}{lcccr}
\hline Model & R & R Square & Adjusted R Square & Std. Error of the Estimate \\
\hline 1 & $.408^{\mathrm{a}}$ & .166 & .153 & 4.118 \\
\hline
\end{tabular}

Hasil output IBM SPSS Statistic pada Tabel 10 diperoleh besar kontribusi sarana pembelajaran dan motivasi siswa terhadap hasil belajar IPS kelas IV di SD di Gugus V Kecamatan Karangasem , (r) yaitu 0,408 apabila dibandingkan dengan harga $r_{\text {tabel }}$ pada taraf signifikansi 5\% yakni 0,176 jadi dapat disimpulkan bahwa $\mathrm{r}_{\text {hitung }} 0,408>\mathrm{r}_{\text {tabel }}$ 0,176 maka $\mathrm{H}_{0}$ ditolak yang berarti signifikan. Sedangkan besar koefisien determinasinya $\left(\mathrm{r}^{2}\right)=0,135$ jadi $0,166 \times 100 \%=16,6 \%$. Jadi besar koefisien determinasinya adalah $16,6 \%$

Tabel 11. Hasil Analisis Besar Koefisien Regresi Ganda $X_{1} X_{2}{ }^{*} Y$

\begin{tabular}{llrrrrr}
\hline Model & & Sum of Squares & Df & Mean Square & F & Sig. \\
\hline 1 & Regression & 418.838 & 2 & 209.419 & 12.349 & $.000^{\mathrm{b}}$ \\
& Residual & 2102.894 & 124 & 16.959 & & \\
& Total & 2521.732 & 126 & & & \\
\hline
\end{tabular}


Dari hasil perhitungan output SPSS pada Tabel 11 diperoleh hasil $\mathrm{F}_{\text {hitung }}=12,349$ dengan signifikansi 0,000, apabila harga $F_{\text {tabel }}$ dibandingkan dengan $F_{\text {hitung }}$ yaitu $F_{\text {tabel }} 12,349>F_{\text {hitung }} 3,080$ ini berarti hasil penelitian signifikan. Dengan demikian hipotesis IV yang menyatakan terdapat hubungan signifikan antara sarana pembelajaran dan motivasi siswa dengan hasil belajar IPS siswa kelas IV di SD Gugus V Kecamatan Karangasem Tahun Pelajaran 2017/2018, diterima

Tabel 12 Hasil Analisis Uji Regresi Ganda $\mathrm{X}_{1} \mathrm{X}_{2}{ }^{*} \mathrm{Y}$

\begin{tabular}{|c|c|c|c|c|c|}
\hline \multicolumn{6}{|c|}{ Coefficients $^{\mathrm{a}}$} \\
\hline & $\begin{array}{l}\text { Unstandard } \\
\text { Coefficients }\end{array}$ & & $\begin{array}{c}\text { Standardized } \\
\text { Coefficients }\end{array}$ & & \\
\hline Model & $\mathrm{B}$ & Std. Error & Beta & $\mathrm{T}$ & Sig. \\
\hline (Constant) & 58.315 & 5.402 & & 10.796 & .000 \\
\hline Sarana Pembelajaran & .053 & .064 & .089 & .825 & .411 \\
\hline Motivasi Siswa & .132 & .041 & .345 & 3.205 & .002 \\
\hline
\end{tabular}

Hasil output IBM SPSS Statistic pada Tabel 12 diperoleh persamaan garis regresi dari variabel sarana pembelajaran dan motivasi siswa terhadap hasil belajar IPS yaitu Y=58,315 +0,053+0,132, di mana $\mathrm{Y}$ adalah hasil belajar IPS, $\mathrm{X}_{1}$ sarana pembelajaran, dan $\mathrm{X}_{2}$ motivasi siwa. Ini berarti koefisien regresi sarana pembelajaran dan motivasi siswa menunjukkan hubungan positif dan artinya semakin lengkap sarana pembelajaran dan semakin tinggi motivasi yang dimiliki siswa maka semakin tinggi pula hasil belajar IPS siswa.Dari hasil analisis di atas, uji hipotesis secara ringkas pada tabel 4.22.

Tabel 13. Rekapitulasi Hasil Analisis Data Pada Uji Hipotesis

\begin{tabular}{cccccc}
\hline \multirow{2}{*}{ Variabel } & $\mathrm{r}_{\text {hitung }}$ & \multirow{2}{*}{$\mathrm{r}_{\text {tabel }}$} & Koefisien determinasi & \multicolumn{2}{c}{ Hipotesis } \\
\cline { 5 - 6 } & 0,311 & 0,176 & $9,7 \%$ & $\mathrm{H}_{\mathrm{a}}$ & $\mathrm{H}_{\mathrm{o}}$ \\
\hline $\mathrm{r}_{\mathrm{xiy}}$ & 0,402 & 0,176 & $16,2 \%$ & Diterima & Ditolak \\
$\mathrm{r}_{\mathrm{x} 2 \mathrm{y}}$ & 0,408 & 0,176 & $16,6 \%$ & Diterima & Ditolak \\
$\mathrm{R}_{\mathrm{x} 1 \mathrm{x} 2 \mathrm{y}}$ & 0 & Diterima & Ditolak \\
\hline
\end{tabular}

Untuk mengetahui berapa persen (\%) sumbangan efektif (SE) dan sumbangan relatif (SR) yang diberikan variabel bebas sarana pembelajaran $\left(\mathrm{X}_{1}\right)$ dan motivasi siswa $\left(\mathrm{X}_{2}\right)$ terhadap variabel terikat hasil belajar IPS (Y) dihitung . untuk mempermudah melakukan perhitungan SE dan SR maka perlu diringkas hasil tabel korelasi. Adapun ringkasan analisis korelasi dan regresi adalah sebagai berikut

Tabel 14 .Ringkasan Analisis Korelasi Dan Regresi

\begin{tabular}{lllll}
\hline No & Variabel & Koefisien regresi (Beta) & Koefisien korelasi (r) & $\mathbf{R}^{2}$ \\
\hline 1 & $\mathrm{X} 1$ & 0,089 & 0,311 & 0,166 \\
2 & $\mathrm{X} 2$ & 0,345 & 0,402 & \\
\hline
\end{tabular}

Sarana pembelajaran merupakan salah satu faktor penting yang dapat menunjang proses pembelajaran. Sarana pembelajaran juga berhubungan dengan hasil belajar siswa. Mulyasa (2004:49) "sarana pembelajaran adalah peralatan dan perlengkapan yang secara langsung dipergunakan dan menunjang proses pendidikan, khususnya dalam proses belajar mengajar. Sarana pembelajaran adalah alat penunjang dalam proses belajar untuk mencapai hasil yang diharapkan sesuai dengan rencana pembelajaran. Sarana pembelajaran yang lengkap dapat memenuhi kebutuhan siswa dalam proses belajar sehingga hasil belajar IPS siswa juga dapat ditingkatkan. Menurut Bahri (2006:150) "anak didik tentu dapat belajar dengan baik dan menyenangkan bila suatu sekolah dapat memenuhi segala kebutuhan belajar anak didik". Sarana pembelajaran yang lengkap akan menjadi faktor tercapainya hasil belajar IPS yang optimal. Sarana pembelajaran yang ada di setiap sekolah itu berbeda-beda, ada yang sudah lengkap dan adapula yang belum. Hal ini akan mempengaruhi proses belajar mengajar IPS, artinya semakin lengkap sarana pembelajaran semakin baik pula nilai yang didapatkan terhadap hasil belajar IPS tersebut. Dengan adanya keperluan sarana yang digunakan untuk menunjang proses pembelajaran diharapkan kepala sekolah maupun guru dapat memenuhi keperluan tersebut sehingga tercipta suasana belajar yang menyenangkan dan siswa senang mengikuti pembelajaran. 
Hal ini terbukti dari hasil analisis yang telah dilakukan , persamaan garis regresi $\hat{Y}=59,036+0,186$ dengan $F_{\text {hitung }}=3,665$. Sumbangan sarana pembelajaran yang diberikan siswa terhadap hasil belajar IPS sebesar $9,7 \%$. Selain sarana pembelajaran, motivasi siswa juga merupakan faktor yang berhubungan dengan hasil belajar. Pada proses pembelajaran motivasi penting adanya dalam menunjang aktifitas belajar siswa. "Motivasi adalah dorongan dasar yang menggerakkan orang bertingkah laku" (Uno, 2008:1). Sardiman (dalam Kardi, 2013:5) menyatakan bahwa "motivasi belajar dapat juga diartikan sebagai serangkaian usaha untuk menyediakan kondisi-kondisi tertentu, sehingga seseorang mau dan ingin melakukan sesuatu, dan bila ia tidak suka, maka akan berusahauntuk meniadakan atau mengelak perasaan tidak suka itu". Motivasi mempunyai peranan yang strategis dalam aktivitas belajar seseorang. Tidak ada seorangpun yang belajar tanpa motivasi. Tidak ada motivasi berarti tidak ada kegiatan belajar. Agar peranan motivasi lebih optimal, maka prinsip-prinsip motivasi dalam belajar tidak hanya sekadar diketahui, tetapi harus diterangkan dalam aktivitas belajar mengajar. Motivasi belajar merupakan dorongan dasar yang menggerakkan seseorang bertingkah laku. Apabila dorongan itu tinggi, maka keberhasilan akan semakin besar untuk tercapai. Motivasi yang ada pada setiap individu berbeda-beda tergantung pada individu itu sendiri. Apabila motivasi belajar tinggi, maka hasil belajar IPS bisa meningkat dengan optimal.

Hal ini terbukti dari hasil analaisis data yang telah dilakukan, persamaan garis regresi $\hat{Y}=61,585+$ $0,153 \mathrm{X}_{2}$ dengan $\mathrm{F}_{\text {hitung }}=4.907$. Sumbangan motivasi belajar yang diberikan siswa terhadap hasil belajar IPS sebesar $16,2 \%$.

Sarana pembelajaran dan motivasi siswa memiliki hubungan dengan hasil belajar. Apabila sarana pembelajaran lengkap serta motivasi siswa tinggi untuk belajar, maka dapat meningkatkan hasil belajar IPS siswa. Begitu pula sebaliknya, apabila sarana pembelajaran kurang dan motivasi siswa rendah, maka diduga berdampak pada rendahnya hasil belajar IPS siswa.

Berdasarkan hasil korelasi regresi ganda antara sarana pembelajaran dan motivasi belajar ditemukan korelasi yang positif dan signifikan dengan hasil belajar IPS. Hal ini terbukti hasil analaisis data yang telah dilakukan, persamaan garis regresi $\hat{\mathrm{Y}}=58.315 \mathrm{Y}+0,053 \mathrm{X}_{1}+0,132 \mathrm{X}_{2}$ dengan $\mathrm{F}_{\text {hitung }}=$ 12.349. Sumbangan sarana pembelajaran dan motivasi belajar terhadap hasil belajar IPS sebesar $16,6 \%$. Dalam penelitian ini ditemukan korelasi yang positif dan signifikan yang berarti semakin lengkap sarana pembelajaran yang ada pada sekolah tersebut dan motivasi belajar yang tinggi maka semakin tinggi pula hasil belajar IPS siswa. Dengan demikian, dapat disimpulkan bahwa terdapat hubungan yang signifikan antara sarana pembelajaran $\left(\mathrm{X}_{1}\right)$ dan motivasi belajar $\left(\mathrm{X}_{2}\right)$ secara bersama-sama dengan hasil belajar IPS (Y) siswa kelas IV SD Gugus V di Kecamatan Karangasem Tahun Pelajaran 2017/2018.

\section{Simpulan dan Saran}

Berdasarkan Hasil penelitian dan analisis data statistik, maka dapat disimpulkan sebagai berikut; 1) Terdapat hubungan yang signifikan antara sarana pembelajaran dengan hasil belajar IPS siswa kelas IV di SD Gugus V Kecamatan Karangasem tahun pelajaran 2017/2018, 2) Terdapat hubungan yang signifikan antara motivasi siswa dengan hasil belajar IPS siswa kelas IV di SD Gugus V kecamatan Karangasem tahun pelajaran $2017 / 2018$, 3) Terdapat hubungan yang signifikan antara sarana pembelajaran dan motivasi siswa dengan hasil belajar IPS siswa kelas IV di SD Gugus V Kecamatan Karangasem tahun pelajaran $2017 / 2018$.

Berdasarkan simpulan di atas saran peneliti bagi siswa, disarankan untuk bersemangat dalam belajar, memanfaatkan sarana pembelajaran yang disediakan oleh sekolah sehingga mampu mencapai hasil belajar yang optimal. Bagi guru, disarankan untuk memperhatikan saran pembelajaran yang ada disekolah agar mampu menunjang kegiatan belajar siswa dan memotivasi siswa agar mampu meningkatkan hasil belajar siswa. Bagi sekolah, disarankan agar selalu memperhatikan faktor-faktor penunjang kegiatan belajar siswa seperti sarana pembelajaran agar kegiatan belajar mampu menjadi menarik dan membangkikan motivasi siswa sehingga mampu memperoleh hasil yang optimal. Bagi kepala sekolah, disarankan untuk selalu memperhatikan hal-hal apa saja yang perlu ditingkatkan di sekolah yang dapat membantu siswa dalam meningkatkan motivasi dan hasil belajar siswa. Bagi peneliti lain, disarankan untuk melakukan penelitian yang sejenis dalam lingkup yang lebih luas, dan semoga penelitian ini bermanfaat bagi pihak-pihak yang melakukan penelitian ini.

\section{Daftar Rujukan}

Agung, A. A. Gede. 2014. Metodologi Penelitian Pendidikan. Yogyakarta: Aditya Media Publishing.

Djamarah, S. B. 2006. Psikologi Belajar. Jakarta: PT. Rineka Cipta. 
Hadiyanto, Siswantari, dan Umaedi. 2010. Manajemen Berbasis Sekolah. Jakarta: Universitas Terbuka.

Kardi, I. W. 2013. Hubungan Antara Kecerdasan Emosional Dan Motivasi siswa Terhadap Hasil Belajar Ipa Siswa Kelas V Sdn Kelurahan Kintamani Tahun Pelajaran 2012/2013. Tersedia pada https://ejournal.undiksha.ac.id/index.php/JPGSD/article/view/1247/1110Mimbar Undiksha. (diakses tanggal 29 Januari 2018)

Koyan, I. W. 2012. Statistik Pendidikan. Singaraja: Universitas Pendidikan Ganesha Press.

Megawati, Priarti. 2012. Meretas Permasalahan Pendidikan Di Indonesia . Jurnal Formatif 2(3): 227-234 ISSN: 2088-351X

Muhammad, L. 1993. Proses Belajar Mengajar Pola C.B.S.A. Surabaya: Usaha Nasional.

Munirah. 2015. Sistem Pendidikan Di Indonesia: Antara Keinginan Dan Realita . Jurnal AULADUNA, VOL. 2 NO. 2 DESEMBER 2015: 233-245

Mulyasa, E. 2004. Manajemen Berbasis Sekolah. Bandung: PT Remaja Roosdakarya.

Saputra, Y. A. 2016. Hubungan Antara Motivasi siswa Dan Fasilitas Belajar Dengan Prestasi Belajar Ips Pada Siswa Kelas IV SD Negeri 7 Bandung-Baru Pringsewu. Diunduh pada: http// digilib.unila.ac.id/ (diakses pada tanggal 4 Januari 2018)

Saat, Sulaiman. 2015. Faktor-Faktor Determinan Dalam Pendidikan Studi Tentang Makna Dan Kedudukannya Dalam Pendidikan . Jurnal Al-Ta'dib Vol. 8 No. 2, Juli-Desember 2015

Slameto. 2010. Belajar \& Faktor-faktor Yang Mempengaruhi. Jakarta : Rineka Cipta

Sulistyowati.2006. Administrasi Sarana dan Prasarana Pendidikan. Malang: Pusat Pengembangan Penataran Guru IPS dan PMP Malang

Uno, H. B. 2008. Teori Motivasi \& Pengukurannya. Jakarta: PT Bumi Aksara

Widodo, 2013. Peningkatan Aktivitas Belajar Dan Hasil Belajar Siswa Dengan Metode Problem Based Learning Pada Siswa Kelas Viia Mts Negeri Donomulyo Kulon Progo Tahun Pelajaran 2012/2013. Jurnal Fisika Indonesia No: 49, Vol XVII, Edisi April 2013 ISSN : 1410-2994 